\title{
A comparison of markers for estimating magnitude of rumen digestion
}

\author{
By M. J. DRENNAN, ${ }^{*}$ J. H. G. HOLMES AND W. N. GARRETT \\ Department of Animal Science, University of California, Davis, California, USA
}

(Received 22 December r969-Accepted I9 fune 1970)

\begin{abstract}
1. Two experiments were carried out with sheep and cattle receiving high-concentrate rations to estimate the amount of digestion taking place in the rumino-reticulum and omasum. Two techniques were used for the collection of samples of abomasal contents. In the experiment with sheep, animals were slaughtered at different times after feeding and samples of digesta were collected. In the experiment with cattle, samples were collected through an abomasal fistula at $2 \mathrm{~h}$ intervals throughout the entire $24 \mathrm{~h}$. Chromic oxide powder was incorporated into the ration.

2. Digestion of $D M$ in the rumen estimated by the chromic oxide ratio ranged from 36 to $-7 \%$. Estimates based on the lignin ratio ranged from 57 to $68 \%$. Estimates based on lignin as the marker were more consistent within experiments.

3. Starch digestion in the rumen based on the chromic oxide ratio ranged from 56 to $92 \%$ while estimates based on the lignin ratio ranged from 89 to $96 \%$. The amount of starch digested, according to chromic oxide ratios, was up to $500 \mathrm{~g}$ more than estimated organic matter digested in sheep, and up to $2 \mathrm{~kg}$ more than organic matter digested in cattle, both impossible results. Estimates based on lignin were always less than estimated dry-matter digestion.

4. In view of the untenable results obtained by using chromic oxide powder mixed in the ration as an indigestible marker, while lignin in the same samples always yielded credible results, it appears that chromic oxide is not always a suitable marker for estimating rumen digestion from abomasal samples.
\end{abstract}

Armstrong \& Beever (1969) have recently reviewed a number of papers dealing with the extent of starch digestion in different parts of the gut of ruminants receiving rations high in starch. In general, the estimates could be divided into two groups; either $60-85 \%$ of starch was digested in the rumen when the grain given was ground maize, or $90-95 \%$ was fermented if flaked maize or other grains were used. However, Armstrong \& Beever (1969) did not mention that all those who examined ground maize used, as the indigestible marker, chromic oxide powder either mixed with the ration or administered in gelatin capsules, and collected their samples from abomasal fistulas. Many of those investigators who worked with other grains or flaked maize used total collection of digesta from duodenal cannulas. Those who used abomasal fistulas either used different markers, e.g. polyethylene glycol, or paper impregnated with chromic oxide. This impregnated paper released the marker more slowly than the capsules or mixed feed (Corbett, Greenhalgh \& MacDonald, 1958). We have performed two experiments to measure the amount of rumen digestion occurring when milo, steam-processed in two different ways, is fed to sheep and cattle. The results of this comparison, using lignin as a marker, have been reported (Holmes, Drennan \& Garrett, I970). The rations also included chromic oxide powder as a marker, mixed with the feed. The results when chromic oxide powder was used, reported here, suggest that

* Present address: The Agricultural Institute, Grange, Dunsany, Co. Meath, Ireland. 
under the conditions of our experiments this marker leaves the rumen much more rapidly than the ingesta, and throw grave doubt on the value of this substance as a marker for rumen studies when used in this way.

\section{EXPERIMENTAL}

\section{Rations}

The composition of the rations used is given in Table $\mathrm{I}$. Ration 8 AP contained grain which had been steamed at atmospheric pressure for $8 \mathrm{~min}$ before rolling, while the grain in ration $3.5 \mathrm{KP}$ had been steamed at $3.5 \mathrm{~kg} / \mathrm{cm}^{2}$ for $1.5 \mathrm{~min}$ before rolling. The chromic oxide was added to the ration as a powder before mixing. The fat and molasses present prevented any settling of fine particles, as was shown by analysis of the foods sampled throughout the experiment.

Table $\mathrm{r}$. Composition of the ration given to sheep in Expt $\mathrm{I}$ and to cattle in Expt 2

$\begin{array}{lr}\text { Milo } & 80 \cdot 0 \\ \text { Lucerne hay } & 2 \cdot 6 \\ \text { Oat hay } & 2 \cdot 5 \\ \text { Cottonseed meal } & 4 \cdot 0 \\ \text { Molasses } & 5 \cdot 0 \\ \text { Fat } & 2 \cdot 0 \\ \text { Urea } & 1 \cdot 0 \\ \text { Trace-mineral salt } & 1 \cdot 0 \\ \text { Dicalcium phosphate } & 0 \cdot 6 \\ \text { Calcium chloride } & 1 \cdot 0 \\ \text { Chromic oxide } & 0.3\end{array}$

$\begin{array}{lcc}\text { Analysis on } & \text { Ration } 8 \text { AP* } & \text { Ration } 3.5 \mathrm{KP}+ \\ \text { dry-matter basis } & \% & \% \\ & 62.8 & 62.6 \\ \text { Starch } & 2.84 & 2.57 \\ \text { Lignin } & 5.94 & 6.16 \\ \text { Ash } & 13.5 & 13.5 \\ \text { Crude protein } & 0.34 \mathrm{I} & 0.347\end{array}$

* Containing grain which had been steamed at atmospheric pressure for $8 \mathrm{~min}$ before rolling.

$\uparrow$ Containing grain which had been steamed at $3.5 \mathrm{~kg} / \mathrm{cm}^{2}$ for $1.5 \mathrm{~min}$ before rolling.

\section{Design of experiments}

Expt I. Eight I 5-month-old cross-bred wethers weighing about $65 \mathrm{~kg}$ were kept singly in pens. Each ration was given $a d l i b$. to four sheep, fresh food being added at 08.00 hours and 16.00 hours. After 5 weeks on the rations, the sheep were slaughtered, two on each ration at 10.00 hours and two at $\mathbf{1 2 . 0 0}$ hours. These times were chosen to allow collection of rumen samples at a time of high fermentative activity. The viscera were removed as rapidly as possible; ligatures were placed at the cardia, reticuloomasal orifice, omasal-abomasal junction and pylorus. A sample of rumen contents 
was removed as quickly as possible, and was used for estimation of fermentation rate. Results are reported by Holmes et al. (1970). The viscera were cooled in ice until samples were collected from the rumino-reticulum and abomasum. Samples were stored at $-15^{\circ}$ until freeze-dried and ground for determination of starch and nitrogen. Lignin, chromic oxide and ash were determined on samples dried at $60^{\circ}$ for $4^{8} \mathrm{~h}$. The faecal samples for starch and nitrogen determination were collected by a sampling procedure similar to that used in Expt 2. Lignin, chromic oxide and ash were determined in samples from total faeces collections over a $14 \mathrm{~d}$ period and dried at $60^{\circ}$ for $48 \mathrm{~h}$.

Expt 2. The methods of sample collection were designed to repeat the procedure of Tucker, Mitchell \& Little (1968). The rations were the same as in Expt I. Three $300 \mathrm{~kg}$ Holstein steers with abomasal fistulas were used. The fistulas were placed in the abomasum about $20-30 \mathrm{~cm}$ from the pylorus, and closed with modified sheep rumen cannulas, $2.5 \mathrm{~cm}$ internal diameter (Jarrett, 1948). One steer received ration $8 \mathrm{AP}$ and two received ration $3.5 \mathrm{KP}$ ad lib. for 5 weeks, then the rations were exchanged and the procedure was repeated. During the last $\mathrm{r} 2 \mathrm{~d}$ of each period, $200 \mathrm{ml}$ samples were collected from the fistulas at $12 \mathrm{~h}$ intervals advancing $2 \mathrm{~h}$ each day so that twenty-four samples were collected, two for each even-numbered hour of the day. Faecal grab-samples were collected at the same time. The cannulas were closed with plugs which extended the full length of the cannula to prevent ingesta from accumulating within the cannula. Ingesta gushed forth when the plugs were withdrawn, so no separation of ingesta fractions should have occurred. Samples were immediately cooled in ice and stored at $-15^{\circ}$ until freeze-dried. A composite sample for each animal was prepared from equal weights of the dried samples. Individual samples were not analysed.

\section{Analytical methods}

Chromic oxide was determined by the method of Kimura \& Miller (1957). All analyses were run against standards and blanks containing chromic oxide-free feed or faecal material. Recovery of chromic oxide from standards in this laboratory ranges from 98 to $102 \%$. Starch was measured by acid hydrolysis followed by estimation of glucose by the ferricyanide method in a Technicon AutoAnalyzer (Holmes et al. 1970). Lignin was determined by the Association of Official Agricultural Chemists (I960) second method. Nitrogen was measured by the macro-Kjeldahl method. Digestibility was calculated from the formulas:

$$
\begin{aligned}
& \% \text { Dry-matter digestibility }=100-\frac{\text { marker in feed }}{\text { marker in faeces }} \times 100 ; \\
& \% \text { Starch digestibility }=100-\frac{\text { marker in feed }}{\text { marker in faeces }} \times \frac{\text { starch in faeces }}{\text { starch in feed }} \times 100 .
\end{aligned}
$$

\section{RESULTS}

Expt I

The compositions of abomasal contents and faeces are given in Table 2. Means with their standard errors for digestibility and amounts digested are given in Table 3 
for lignin-based estimates. Estimates from chromic oxide are given in Table 4. Voluntary intake of ration $8 \mathrm{AP}$ was more variable than that ration $3.5 \mathrm{KP}$ owing to one animal eating $2000 \mathrm{~g} / \mathrm{d}$ while the other three ate between $145^{2}$ and $1563 \mathrm{~g} / \mathrm{d}$; consequently, the standard errors of all quantitative results are large. Standard errors of digestibility estimates were no larger for this feed than for ration $3.5 \mathrm{KP}$. In Table 3, the errors for all results for the dry matter (DM) with ration $3.5 \mathrm{KP}$ were large because the abomasum of one sheep contained a large amount of sand; in this sheep the ash content was $5 \mathrm{I} \%$. There was no consistent difference between results from the two times of slaughter; the results have, therefore, been combined.

Table 2. Expt I. Composition, expressed on an oven-dry basis, of abomasal contents and faeces of sheep receiving diets in which the milo had been steamed at atmospheric $(A P)$ or a high $(K P)$ pressure*

\begin{tabular}{|c|c|c|c|c|}
\hline & Rati & AP & Ratic & $\mathrm{KP}$ \\
\hline & Abomasum & Faeces & Abomasum & Faeces \\
\hline Ash $(\%)$ & $14 \cdot 36 \pm 3.04$ & $14.94 \pm 0.50$ & $22 \cdot 89 \pm 9 \cdot 55$ & $15.80 \pm 0.13$ \\
\hline Organic matter (\%) & $85.64 \pm 3.04$ & $85.06 \pm 0.50$ & $77 \cdot 1$ I $\pm 9 \cdot 55$ & $84.20 \pm 0.13$ \\
\hline $\operatorname{Starch}(\%)$ & $25.07 \pm 2.91$ & II $53 \pm I \cdot 55$ & $11 \cdot 88 \pm 3 \cdot 12$ & I I $74 \pm 0.71$ \\
\hline $\begin{array}{l}\text { Crude protein }(\%) \\
(\mathrm{N} \times 6.25)\end{array}$ & $25.45 \pm 2 \cdot 57$ & $27.75 \pm 0.71$ & $29.72 \pm 3.30$ & $26.33 \pm 0.87$ \\
\hline Lignin $(\%)$ & $9.13 \pm 0.71$ & $x 7 \cdot 28 \pm 0 \cdot 93$ & $7 \cdot 02 \pm I \cdot 19$ & I $5.66 \pm 0.44$ \\
\hline Chromic oxide $(\mathrm{mg} / \mathrm{g}$ ) & $3.28 \pm 0.33$ & $18.25 \pm 0.94$ & $3.67 \pm 0.27$ & $18.36 \pm 0.63$ \\
\hline
\end{tabular}

* Details of the preparation of the grain are given on p. 962 .

The estimates of the degree of digestion in the rumen varied widely depending on the marker used. For both rations, lignin gave estimates of digestibility of organic matter $(\mathrm{OM})$ and $\mathrm{DM}$ in the rumen of $57-71 \%$ with standard errors of about $2 \%$. The estimates for digestibility in the rumen based on chromic oxide ranged from -7 to $+22 \%$; the standard errors ranged from 6.82 to 9.68 percentage units. The estimates for digestibility of starch based on chromic oxide were considerably lower and more variable than those based on lignin. When the amounts of material digested are examined, further anomalous results appear. When lignin was used, the weight of starch digested in the rumen was less than the weight of OM digested. However, when chromic oxide was used, the estimated digestion of starch exceeded the OM digested by about $500 \mathrm{~g}$. Digestibility of nitrogen anterior to the abomasum was less than the digestibility of any other food component. However, the samples included the abomasal secretions which would greatly increase the concentration of protein. Lignin-based estimates indicated significant absorption, while chromic oxide calculations indicated that the endogenous protein added resulted in twice as much protein leaving the abomasum as was given.

\section{Expt 2}

Voluntary intakes of the two diets were similar (Table 6). The composition of abomasal digesta and faeces is given in Table 5 ; the estimates of digestion determined with lignin are given in Table 6 , and those determined with chromic oxide in Table 7. As in Expt $\mathrm{I}$, the estimates of DM digestion in the rumen were about 
Vol. 24

Markers for measuring rumen fermentation

2

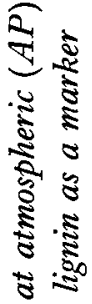

焉害运

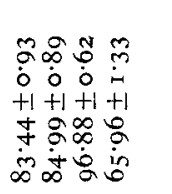

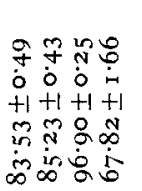

छ

ฐั

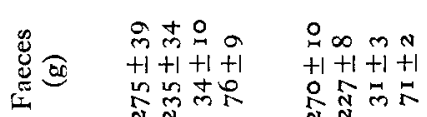

.

离

空

ฐँ

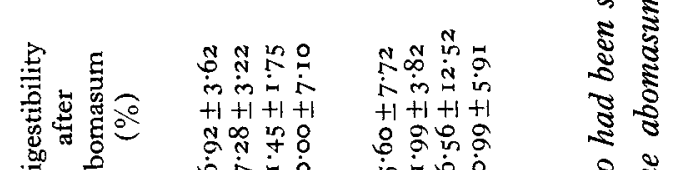

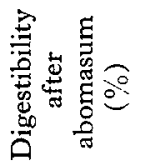

焉莺

$2+\infty 8$

$8: \pm 0$

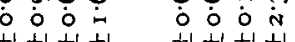

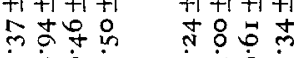

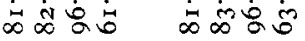

$\frac{2}{2}$

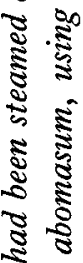

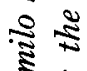

ค

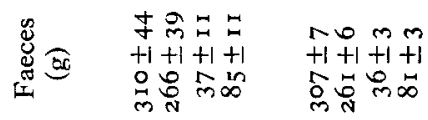

ลิ

离

E $N$ 的舟

今。ㅇํㅇ

ถู

ह ะ

悉

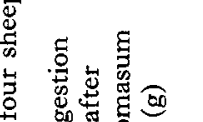

20

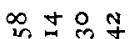

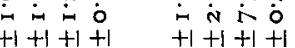

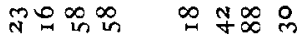

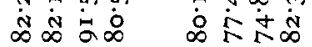

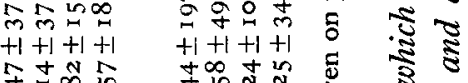

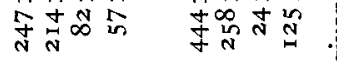

. 5

(1)

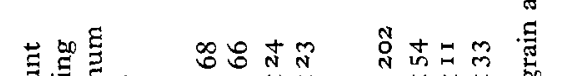
$+1+1+1+1 \quad+1+1+1+1$

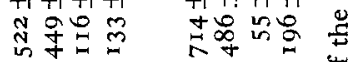

离

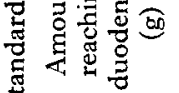

ह है

$\frac{8}{2} \frac{8}{2}$

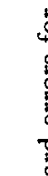

.

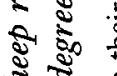

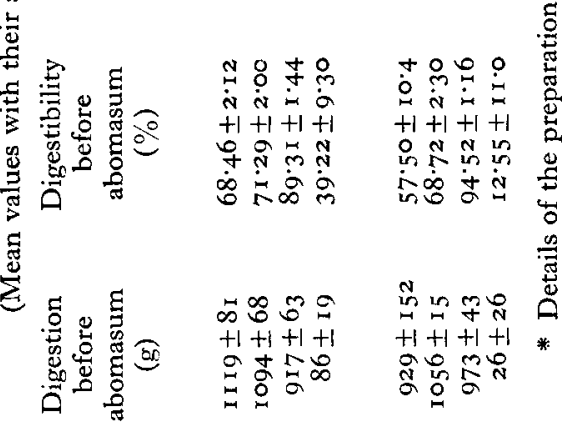

ฐ

इूँ है

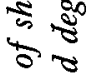

章

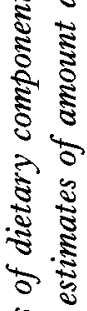

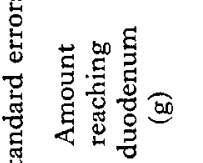

$\infty \%+\%$

2
$+1+1+1$

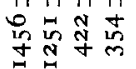

$\tan$

$\pm \approx$ in

全柴金

\%응

$+1+1+1+1$

员的余学

inํㅡㄹ 츠

$+1+1+1+1$

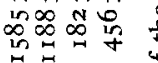

妾

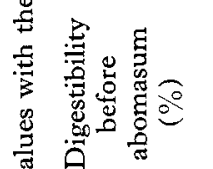

क유ำ

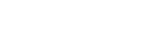

$+1+1+1+$

oำ in

$+1+1+1+1$

रू से⿺

人तi

ल

㞼

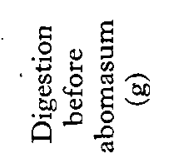

in 8

o in $\infty$

$+1+1+1+1$

$+1+1+1+1$

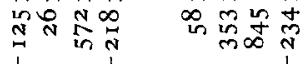

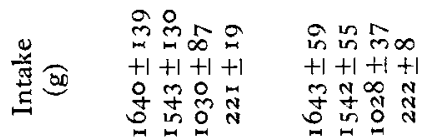

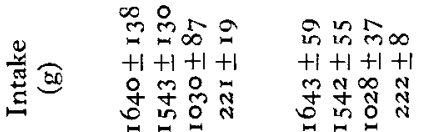

है है

.

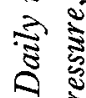

帘

$\therefore \longdiv { 2 }$

सी

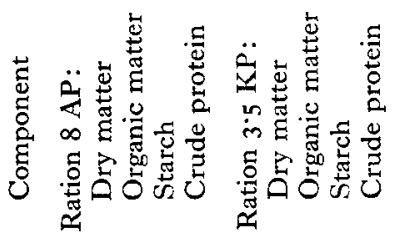

तह

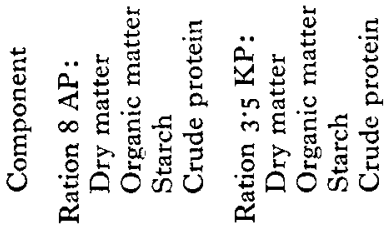


$60-70 \%$ when lignin was used as the marker, but were less than half this value when chromic oxide was used; digestion of OM was also much lower with chromic oxide, and the standard errors were larger. The digestibility of starch measured with chromic oxide was below the lignin estimate and was associated with larger standard errors. The quantitative results were also anomalous, with the weight of starch digested in the rumen exceeding the weight of OM digested by more than $\mathrm{I} \mathrm{kg}$ when chromic oxide was used as the marker, while starch disappearance was about $90 \%$ of OM disappearance when lignin was used.

Table 5. Expt 2. Composition of abomasal contents and faeces of cattle receiving diets in which the milo had been steamed at atmospheric $(A P)$ or a high $(K P)$ pressure, ${ }^{*}$ expressed on an oven-dry basis

(Mean values with their standard errors for three steers)

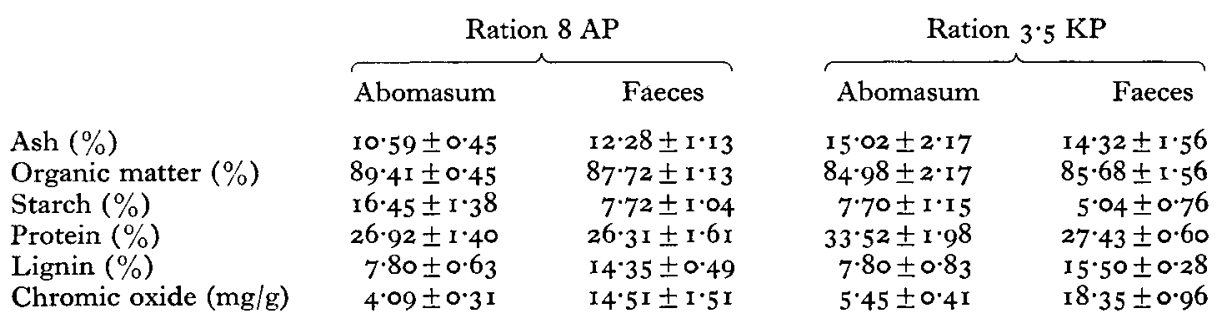

* Details of the preparation of the grain are given on p. 962 .

As in Expt I, digestibility of protein anterior to the fistula was less than the digestibility of starch or OM. The results based on lignin suggest a significant absorption, while those based on chromic oxide suggest a large net secretion of protein into the gut. The estimates of the amount of fermentation occurring in the rumen with the same ration agree closely between Expts I and 2 when lignin was used as the marker, but disagree markedly if chromic oxide was used.

\section{DISCUSSION}

In both experiments, the estimates of the proportion of total digestible DM digested in the rumen based on chromic oxide were lower than estimates based on lignin and lower than the generally accepted values of $60-80 \%$ found by Topps, Kay \& Goodall (1968) or $57-65 \%$ found by Nicholson \& Sutton (1969), while estimates using lignin were within this range. The agreement between estimates of digestion based on lignin is surprisingly good in the two experiments, when it is considered that the results were from different species, collected by different methods and at different times. This suggests that the samples withdrawn from the cattle were accurately representative of abomasal contents, and that the samples from the abomasum of the sheep were representative of the flow throughout the day, unless compensating errors occurred. The abomasal samples collected from the sheep 2 or $4 \mathrm{~h}$ after feeding could have been representative of a major part of the daily flow, but the agreement between the two experiments must be regarded as fortuitous. When the amount of 
Vol. 24

Markers for measuring rumen fermentation

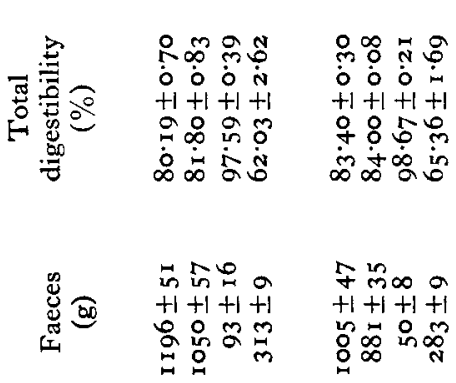

\ิ

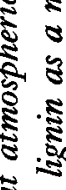

है

要

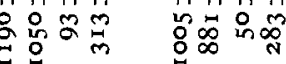

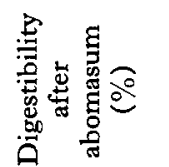

$\therefore \circ$

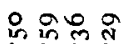

तis is is in in

$+1+1+1+1+1+1+1$

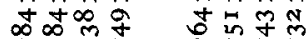

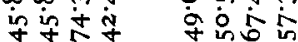

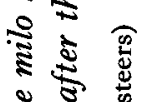

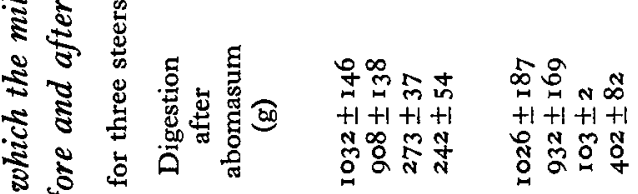

इ

:

so

के

害

है क

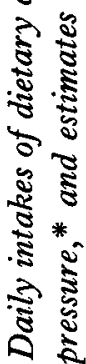

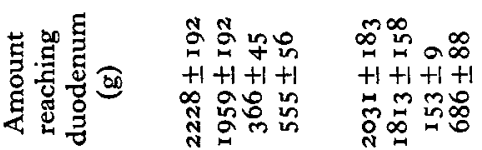

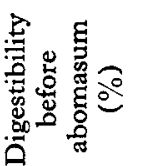

풍

$\dot{m i n}$

궁

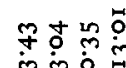

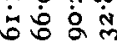

$+1+1+1+$

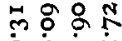

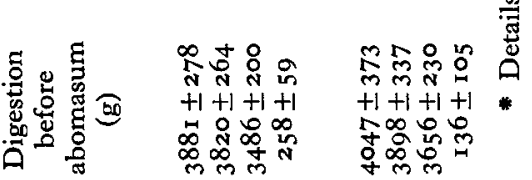

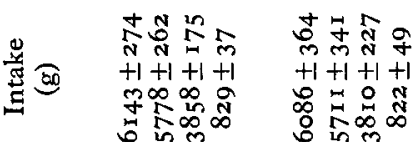

密

ถิ

ป

क

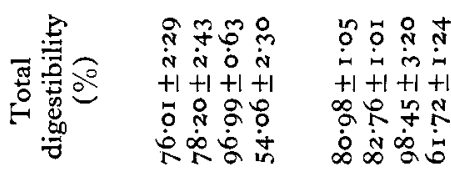

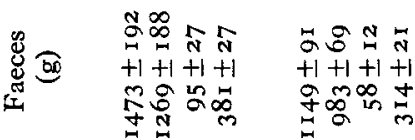

है . จ

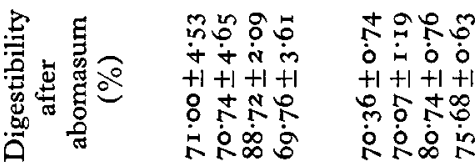

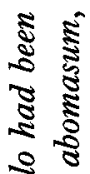

จ

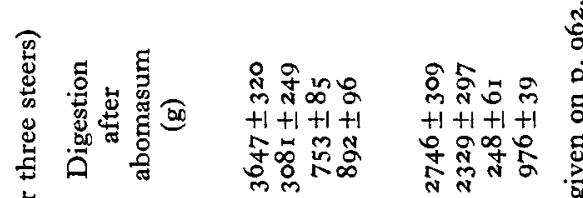

离

.

के

so.

त)

अ

ड़ :

के

है है

ริ

왕

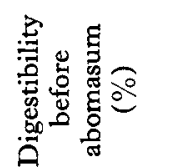

ㅇำ

0

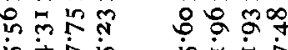

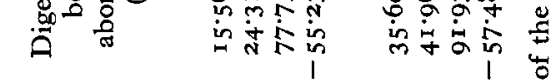

i

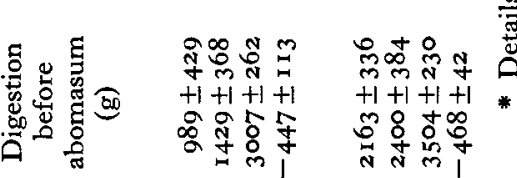

政

证

ช.

ะั

ㄹำ

डิ

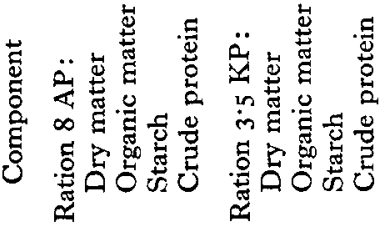

i

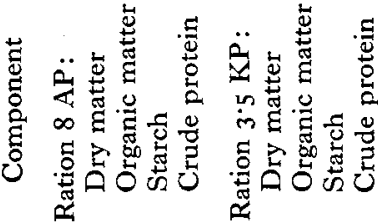

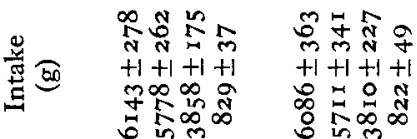

曹

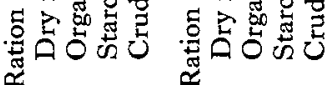


digestion in the rumen was calculated, the use of chromic oxide gave results which were not possible, while the estimates from lignin were quite credible. Some of the starch might be converted into other compounds such as bacterial and protozoal cells and thus contribute to rumen DM but not to rumen starch. But the production of microbial cell material is not adequate to explain the magnitude of the observed discrepancies.

It is possible to calculate the fermentation of starch without calculating the fermentation of DM or OM. If this were done in Expts $\mathrm{I}$ and 2, using the chromic oxide concentrations, the estimates of starch fermentation, ranging from 56 to $92 \%$, might not be thought extraordinary. Neither Karr, Little \& Mitchell (I966) nor Tucker et al. (1968), working with maize, nor MacNeill, Potter \& Riggs (r969), who were working with milo, presented results on the disappearance of DM from the rumen. All these authors have reported low estimates of disappearance of starch from the rumen, from 45 to $85 \%$, and all used chromic oxide powder as a marker and the abomasal sampling procedure, which in our hands yielded impossible results. Karr et al. (1966) and Tucker et al. (1968) recorded highly variable estimates of digestibility between animals. Karr et al. (1966) used chromic oxide powder in gelatin capsules, while Tucker et al. ( 1968 ) used chromic oxide powder mixed with the food.

Topps, Kay \& Goodall (I968) collected total duodenal flow from sheep and sampled this for chromic oxide analysis. Their estimates of starch disappearance were about $92 \%$ for the concentrate ration. Similar estimates of starch digestion were made with sheep with abomasal fistulas. MacRae \& Armstrong (1969a, $b$ ), using re-entrant duodenal cannulas and feeding dairy cubes, flaked maize, and rolled or whole barley, reported starch fermentation in excess of $89.7 \%$; Nicholson \& Sutton (ig69), also using re-entrant duodenal cannulas, estimated starch disappearance in excess of $95 \%$ with rations of flaked maize. Orskov \& Fraser (1968) used polyethylene glycol as a marker and estimated starch disappearance at $87-96 \%$. Topps, Kay, Goodall, Whitelaw \& Reid ( 1968 ) measured rumen fermentation of concentrates containing $85 \%$ barley in steers, using samples from abomasal fistulas and chromic oxide as a marker. Starch disappearance from the rumino-reticulum was about $95 \%$.

In all these experiments, except that of Orskov \& Fraser (I968), the chromic oxide was in the form of impregnated paper placed in the rumen, which has been shown by Langlands, Corbett, McDonald \& Reid (1963) to give a more even release of marker into the faeces. Corbett et al. (1958) measured the concentration of chromic oxide in the duodenum of sheep at hourly intervals following its administration as powder in a gelatin capsule, or as impregnated paper or in a plaster of Paris bolus. After administration of $8 \mathrm{~g}$ in a capsule, concentration in the duodenum at successive hourly intervals was 94, I $30,73,40,25,20 \mathrm{mg} / \mathrm{g} \mathrm{OM}$ and remained below $10 \mathrm{mg} / \mathrm{g}$ OM from the 8 th to the 24th hour. Impregnated paper gave no peak until the 6th hour, and then it was below $30 \mathrm{mg} / \mathrm{g}$. Lambourne \& Reardon ( 1963 ) also found that chromic oxide given as an oily suspension in a capsule passed rapidly out of the rumen. They reviewed the advantages of using paper impregnated with chromic oxide to estimate total digestibility. Johnson, Dinusson \& Bolin (1964) examined the concentration of chromic oxide in all sections of the gut after feeding, and measured the rate of excretion of a single 
dose when given in 'paper' form or as a powder mixed with a pelleted ration. They found that the powder moved through the gut significantly faster than the 'paper' form, and that this difference was established by different rates of passage from the rumen. From their figure 2, it appears that passage from the omasum to abomasum of the 'paper' form was similar to that of lignin. Consequently, chromic oxide concentration in the abomasum might be used to give an accurate estimate of digestion anterior to this point, if the 'paper' form were used. The powder form yielded an abomasal concentration of chromic oxide only $70 \%$ of that found when the paper was used, and would lead to large underestimation of digestion.

In our experiments, the animals were fed at 08.00 hours and 16.00 hours and most of the ingestion occurred shortly after feeding. A peak excretion of chromic oxide into the abomasum of less than $4 \mathrm{~h}$ duration would mean that in the steers in Expt 2 this peak would be represented by high concentration in samples collected at 10.00 hours and $\mathrm{I} 8.00$ hours only, i.e. that high concentrations for up to $8 \mathrm{~h}$ of the day might be represented by two samples/d. This would lead to a marked downward bias in mean concentration, and lowered estimates of digestion. Analysis of individual samples would have been necessary to prove this point.

In Expt I the concentration of chromic oxide in the rumen was equal to or lower than in the food, even in animals slaughtered $2 \mathrm{~h}$ after eating. Fermentation in the rumen was very rapid, and almost complete by $2 \mathrm{~h}$ after feeding (Holmes et al. 1970). The rumens of the sheep contained, on the average, $57 \cdot 2 \%$ and $45.2 \%$ of the daily DM intake for rations $8 \mathrm{AP}$ and $3.5 \mathrm{KP}$, respectively, with no differences between times of slaughter. Flow from the rumen was probably rapid immediately after feeding and may have washed much of the finely divided chromic oxide from the rumen within $2 \mathrm{~h}$.

In summary, the results of our investigations using chromic oxide powder as the marker agree well with estimates obtained by other workers using the same marker and the same sampling techniques, but they are highly improbable. The use of lignin as a marker yielded results for starch disappearance in accord with those of workers who used abomasal samples and paper impregnated with chromic oxide, or polyethylene glycol, or used re-entrant duodenal cannulas and samples of total collections. Estimates of OM disappearance agree with other published values and always exceeded starch disappearance when lignin was used. This does not prove that the lignin-based estimates are correct, but they are at least possible. The difference between estimates with chromic oxide and those with lignin varied between experiments. It is apparent from these studies that chromic oxide powder may not be suited for use as an indigestible marker in the rumen and abomasum, and that this may be due to its very rapid or uneven passage from the rumen. In some experiments, chromic oxide powder may fortuitously give correct results. 


\section{REFERENCES}

Armstrong, D. G. \& Beever, D. E. (1969). Proc. Nutr. Soc. 28, 121.

Association of Official Agricultural Chemists (1960). Official Methods of Analysis 9th ed. Method 6.094, p. 91. Washington, D.C.: Association of Official Agricultural Chemists.

Corbett, J. L., Greenhalgh, J. F. D. \& MacDonald, A. P. (1958). Nature, Lond. 182, I014.

Holmes, J. H. G., Drennan, M. J. \& Garrett, W. N. (1970). F. Anim. Sci. 31, 409.

Jarrett, I. C. (1948). F. Coun. scient. ind. Res. Aust. 2I, 3 I I.

Johnson, D. E., Dinusson, W. E. \& Bolin, D. W. (1964). F. Anim. Sci. 23, 499.

Karr, M. R., Little, C. O. \& Mitchell, G. E. Jr (r966). F. Anim. Sci. 25, 652.

Kimura, F. T. \& Miller, V. L. (r957). F. agric. Fd Chem. 5, 2 I6.

Lambourne, L. J. \& Reardon, T. F. (1963). Aust. F. agric. Res. 14, 239.

Langlands, J. P., Corbett, J. L., McDonald, I. \& Reid, G. W. (I963). Br. F. Nutr. I7, 2 I 1.

MacNeill, J. W., Potter, G. D. \& Riggs, J. K. (1969). F. Anim. Sci. 29, I65.

MacRae, J. C. \& Armstrong, D. G. (1969a). Br. F. Nutr. 23, 5.

MacRae, J. C. \& Armstrong, D. G. (1969b). Br. F. Nutr. 23, 377.

Nicholson, J. W. G. \& Sutton, J. D. (1969). Br. $\mathcal{F}$. Nutr. 23, 585.

Orskov, E. R. \& Fraser, C. (1968). Proc. Nutr. Soc. 27, 37 A.

Topps, J. H., Kay, R. N. B. \& Goodall, E. D. (1968). Br. F. Nutr. 22, 26I.

Topps, J. H., Kay, R. N. B., Goodall, E. D., Whitelaw, F. G. \& Reid, R. S. (1968). Br. F. Nutr. 22,28 I. Tucker, R. E., Mitchell G. E. Jr \& Little, C. O. (1968). F. Anim. Sci. 27, 824. 